\title{
Identification of pTi-SAKURA DNA region conferring enhancement of plasmid incompatibility and stability
}

\author{
Shinji Yamamoto, Misugi Uraji, Katsuyuki Tanaka, \\ Kazuki Moriguchi and Katsunori Suzuki* \\ Department of Biological Science, Graduate School of Science, Hiroshima University, \\ Higashi-Hiroshima, Hiroshima 739-8526, Japan
}

(Received 3 Octoberl 2006, accepted 9 March 2007)

\begin{abstract}
In Agrobacterium tumefaciens, the stability of Ti plasmids differs depending on the strain. So far, little is known about genes that cause the difference in stability. The rep $A B C$ operon is responsible for replication and incompatibility of $\mathrm{Ti}$ plasmids. We constructed recombinant plasmids carrying the rep $A B C$ operon and different portions of pTi-SAKURA. Cells having the recombinant plasmids that harbored a $2.6-\mathrm{kbp}$ NheI fragment of pTi-SAKURA were found to be transformed via conjugation 100 -fold less frequently with a small incompatible repABC plasmid than cells having the recombinant plasmids lacking the $2.6-\mathrm{kbp}$ NheI fragment. Since the phenomenon occurred only when the resident and incoming plasmids belonged to the same incompatibility group, it was suggested that the $2.6-\mathrm{kbp}$ NheI fragment bears the potential enhancing incompatibility. The fragment contained an operon consisting of two open reading frames, tiorf24 and tiorf25. tiorf24 is an orphan gene, whereas tiorf 25 is a homologue of a group of plasmid stability genes. Removal of the $2.6-\mathrm{kbp}$ fragment from the resident pTi-SAKURA increased the resident plasmid ejection ratio by the incoming rep $A B C$ plasmid, whereas addition of the fragment to pTiC58 decreased the ejection ratio, and the loss ratio during growth at $37^{\circ} \mathrm{C}$. These data suggest that tiorf 24 and tiorf 25 are responsible for the stability of pTi-SAKURA, and reduce, in the host bacterium, the frequency of ejection of the resident plasmid, presumably through an incompatibility mechanism.
\end{abstract}

Key words: Agrobacterium, incompatibility, stability, Ti plasmid

\section{INTRODUCTION}

Agrobacterium tumefaciens causes crown gall disease in dicot plants. The tumor-inducing plasmid (Ti) is indispensable for the phytopathogenicity of this bacterium, because it harbors oncogenic genes in its T-DNA region and many virulence genes for infection and T-DNA transport functions. The plasmids are stably maintained at a low copy number in the bacterial cells (at an equimolar ratio with the bacterial linear and circular chromosomes) (Suzuki et al., 2001). The stability of Ti plasmids still differs depending on the strain (Holsters et al., 1982). The stability difference is likely to exert a serious effect on Ti plasmid evolution. The repABC locus is sufficient for autonomous replication of the plasmids (Tabata et al., 1989; Li and Farrand, 2000). To date, the nucleotide

Edited by Fujio Kawamura

* Corresponding author. E-mail: ksuzuki@hiroshima-u.ac.jp sequence of the repABC region of Ti has been determined in an octopine-type plasmid, pTiB6S3 (Tabata et al., 1989), and two nopaline-type plasmids, pTi-SAKURA and pTiC58 (Suzuki et al., 1998; Li and Farrand, 2000).

Rhizobiaceae bacteria commonly possess rep $A B C$ plasmids (Rigottier-Gois et al., 1998). The repABC region consists of three clustered genes (repA, and a replication origin (oriV) required for replication and partitioning. The RepA and RepB proteins are involved in plasmid partitioning and copy number control, which are important for stable inheritance. RepC is an indispensable protein for replication initiation. These genes are organized as an operon (Ramírez-Romero et al., 2000). Thus, the repABC region contains factors for autonomous replication and stable inheritance. Some strains of Rhizobiaceae bacteria possess more than one rep $A B C$ replicon. For instance, A. tumefaciens strain C58 has three repABC replicons: pTiC58, pAtC58 and the linear chromosome, each belonging to three different incompatibility 
groups of the repABC replicon in this strain (Goodner et al., 2001). It is well known that most Ti plasmids belong to the same incompatibility group, whereas most Ri plasmids belong to another incompatibility group (White and Nester, 1980).

Incompatibility has been defined as a situation where two plasmids harboring a related replication and/or partitioning system are unable to exist in a cell simultaneously without external selection. The incompatibility phenomenon is considered to be caused by competition for a limited number of components for replication, a partitioning mechanism or by disturbance in plasmid copy number correction (Novick, 1987; Austin and Nordström, 1990). Mini-Ti and -Ri plasmids carrying repABC genes confer their respective incompatibility characteristics (Nishiguchi et al., 1987, Tabata et al., 1989) and two sites in the repABC locus were defined as incompatibility-determining regions in Rhizobium etli p42d (Ramírez-Romero et al., 2000).

Ti plasmids have been practically categorized according to their production and catabolism of opines. pTiC58 and pTi-SAKURA are nopaline-type Ti plasmids. The frequency of ejection of pTi-SAKURA in MAFF301001 by transformation via conjugation of the strain with an incompatible small repABC plasmid is much lower than that of pTiC58 in the C58 strain (Uraji et al., 2002). The two Ti plasmids are almost identical along $60 \%$ of their length (200 kbp), but the remaining regions exhibit no or very low levels of homology. We named the largest nonhomologous region VAR (large variable region) (Suzuki et al., 2000). Because VAR contains many genes whose functions are unidentified (Hattori et al., 2000), we hypothesized that the factor causing the difference of the ejection frequency between the two $\mathrm{Ti}$ plasmids is contained within VAR. In the present study, we localized and characterized the factor within VAR of pTi-SAKURA which can enhance incompatibility in small repABC plasmids and increase the stability of pTiC58.

\section{MATERIALS AND METHODS}

Bacterial strains and culture conditions Bacterial strains and plasmids used in this study are listed in Table 1. A. tumefaciens cells were cultured at $28^{\circ} \mathrm{C}$ in $\mathrm{LB}$ medium. Escherichia coli cells were cultured at $37^{\circ} \mathrm{C}$ in LB. When necessary, antibiotics were added to the medium at the following final concentrations: gentamicin (45 $\mu \mathrm{g} / \mathrm{ml})$, kanamycin $(50 \mu \mathrm{g} / \mathrm{ml})$, rifampicin $(40 \mu \mathrm{g} / \mathrm{ml})$, tetracycline $(5 \mu \mathrm{g} / \mathrm{ml})$ and chloramphenicol $(35 \mu \mathrm{g} / \mathrm{ml})$. A. tumefaciens cells were also grown on $\mathrm{AB}$ minimal salts medium (Chilton et al., 1974) supplemented with nopaline as the sole source of carbon instead of glucose.

Plasmid construction and DNA preparation E. coli S17-1 $\lambda$ pir was used as a host strain for plasmid construc- tion and conjugal transfer of mobilizable plasmids (Simon et al., 1983; Penfold and Pemberton, 1992). Fosmid clones containing portions of pTi-SAKURA were selected from an A. tumefaciens MAFF301001 genomic DNA library (De Costa et al., 2001) by colony hybridization using purified pTi-SAKURA DNA as a probe. Among the 14 recombinant fosmids selected, four clones were chosen for the present study. In order to allow the four plasmids to move into, replicate in and be selected in Agrobacterium cells, repABC of pTi-SAKURA, oriT and $\mathrm{Km}^{\mathrm{r}}$ genes were inserted into the four fosmids by homologous recombination in vivo between plasmids in the $r e c A^{+} E$. coli strain LE392. Two fosmid clones, $2 \mathrm{~K} 1$ and 1F23, contained repABC (Fig. 1). They were fused with pJP5603, which contains $\mathrm{Km}^{\mathrm{r}}$ and oriT. The resultant plasmids were named pfK and pfF. The other two fosmids, $1 \mathrm{M} 3$ and 2I19, had no repABC. They were fused with pJP5603rep, which contains $\operatorname{rep} A B C$ in addition to $\mathrm{Km}^{\mathrm{r}}$ and oriT. The resultant plasmids were named pfM and pfI. pfK $\triangle A s c \mathrm{I}$ was constructed by $A s c \mathrm{I}$ digestion of pfK and subsequent self-ligation. pK18msr is a pK18mobsacB plasmid carrying a 4.9-kbp HindIII fragment of pMGTrep 1 (Uraji et al., 2002); the HindIII fragment contains repABC. pN2, pN5, pN7 and pN12 were constructed by inserting each Nhe I fragment of pfK into pK18msr (see Fig. 3). A derivative of $\mathrm{pN} 2$, pN2 $2 \Delta s p \mathrm{~V}$, was constructed by $N s p \mathrm{~V}$ digestion of $\mathrm{pN} 2$ and subsequent self-ligation. pHRPN2 and pBINN2 were constructed by inserting a 2.6-kbp NheI fragment of $\mathrm{pN} 2$ into pHRP311 and pBIN19, respectively. pBINTc was constructed by cloning into pBIN19 a 2.1-kbp Bam HI fragment containing a $\mathrm{Tc}^{\mathrm{r}}$ cassette excised from $\mathrm{pHP} 45 \Omega$ Tc. pN2T-r was constructed by digestion of $\mathrm{pN} 2$ with HindIII followed by self-ligation and insertion of a $1.7-\mathrm{kbp}$ $B g l \mathrm{II}$ fragment of pTiC58 T-DNA. pTiC58px is a fusion plasmid formed in vivo in C58 cells between pN2T-r and pTiC58. pN2G-r was constructed by digestion of $\mathrm{pN} 2 \Delta N s p \mathrm{~V}$ with HindIII followed by self-ligation and insertion of a 2.8-kbp Acc I- $N s p \mathrm{~V}$ fragment containing a $\mathrm{Gm}^{\mathrm{r}}$ cassette from pUC19Gm into a unique $N s p \mathrm{~V}$ site. pTi-SAKURAmx is pTi-SAKURA with a tiorf25::Gm ${ }^{\mathrm{r}}$ mutation, which was formed in vivo in MAFF301001rif cells by replacement of tiorf $25^{+}$with tiorf $25:: \mathrm{Gm}^{\mathrm{r}}$ of $\mathrm{pN} 2 \mathrm{G}-$ $\mathrm{r}$ via double crossover between pTi-SAKURA and $\mathrm{pN} 2 \mathrm{G}-\mathrm{r}$.

DNA manipulations for plasmid construction were performed using standard procedures (Sambrook et al., 1989).

Introduction of plasmid DNA Plasmids were delivered from $E$. coli to A. tumefaciens by conjugal transfer as described elsewhere with some modifications (Uraji et al., 2002). Conjugation efficiency was calculated by dividing the number of transconjugant colonies by the number of donor colonies. Conjugal transfer of plasmids from $E$. coli to $E$. coli was carried out as follows. Donor E. coli 
Table 1. Bacterial strains and plasmids used in this work

\begin{tabular}{|c|c|c|}
\hline $\begin{array}{l}\text { Strain or } \\
\text { plasmid }\end{array}$ & Relevant characteristics & Reference or source \\
\hline \multicolumn{3}{|l|}{ Strains } \\
\hline \multicolumn{3}{|l|}{ A. tumefaciens } \\
\hline MAFF301001rif & Wild-type pathogenic strain carrying pTi-SAKURA, Rif $^{r}$ & Uraji et al., 2002 \\
\hline MNS-1 & pTi-SAKURA-less derivative of the wild-type strain MAFF301001rif & Uraji et al., 2002 \\
\hline C58 & Wild-type pathogenic strain carrying pTiC58 & Goodner et al., 2001 \\
\hline C58 rif & Wild-type pathogenic strain carrying pTiC58, Rif ${ }^{r}$ & This study \\
\hline $\mathrm{C} 58 \mathrm{C} 1$ & 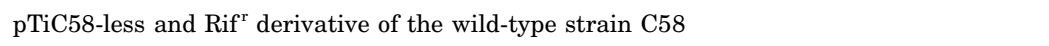 & Our collection \\
\hline \multicolumn{3}{|l|}{ E. coli } \\
\hline Sy327 $\lambda$ pir & $\operatorname{Rif}^{\mathrm{r}} \mathrm{Nal}^{\mathrm{r}} \lambda$ pir & Miller and Mekalanos, 1988 \\
\hline S17-1 $\lambda$ pir & Host strain for recombinant plasmid construction and conjugal transfer; $\operatorname{Sm}^{\mathrm{r}} \lambda$ pir & Simon et al., 1983 \\
\hline LE392 & Host strain for homologous recombination; $\mathrm{rec}^{+}$ & Sambrook et al., 1989 \\
\hline \multicolumn{3}{|l|}{ Plasmids } \\
\hline pTi-SAKURA & Ti plasmid (206,479 bp) of A. tumefaciens MAFF301001 & Suzuki et al., 1998 \\
\hline pTi-SAKURAmx & pTi-SAKURA with tiorf25:: $\mathrm{Gm}^{\mathrm{r}}$ mutation; $\mathrm{Gm}^{\mathrm{r}}$ & This study \\
\hline pTiC58 & Ti plasmid (214,233 bp) of A. tumefaciens $\mathrm{C} 58$ & Goodner et al., 2001 \\
\hline pTiC58px & pTiC58 with an insertion of $2.6-\mathrm{kbp}$ NheI fragment of pTi-SAKURA; $\mathrm{Km}^{\mathrm{r}}$ & This study \\
\hline $2 \mathrm{~K} 1$ & Fosmid clone containing 43.5-kbp HindIII fragment of pTi-SAKURA $(9104-52625)^{*} ; \mathrm{Cm}^{\mathrm{r}}$ & Our collection \\
\hline $1 \mathrm{~F} 23$ & Fosmid clone containing 43.9-kbp HindIII fragment of pTi-SAKURA (4045-47954); $\mathrm{Cm}^{\mathrm{r}}$ & Our collection \\
\hline $1 \mathrm{M} 3$ & Fosmid clone containing 42.3-kbp HindIII fragment of pTi-SAKURA (79831-122160); $\mathrm{Cm}^{\mathrm{r}}$ & Our collection \\
\hline $2 \mathrm{I} 19$ & Fosmid clone containing 37.8-kbp HindIII fragment of pTi-SAKURA (113054-150896); $\mathrm{Cm}^{\mathrm{r}}$ & Our collection \\
\hline $\mathrm{pfK}$ & Co-integrate between $2 \mathrm{~K} 1$ and pJP5603; $\mathrm{Km}^{\mathrm{r}} \mathrm{Cm}^{\mathrm{r}}$ & This study \\
\hline $\mathrm{pfF}$ & Co-integrate between $1 \mathrm{~F} 23$ and pJP5603; $\mathrm{Km}^{\mathrm{r}} \mathrm{Cm}^{\mathrm{r}}$ & This study \\
\hline pfM & Co-integrate between $1 \mathrm{M} 3$ and pJP5603rep; $\mathrm{Km}^{\mathrm{r}} \mathrm{Cm}^{\mathrm{r}}$ & This study \\
\hline pfI & Co-integrate between $2 \mathrm{I} 19$ and pJP5603rep; $\mathrm{Km}^{\mathrm{r}} \mathrm{Cm}^{\mathrm{r}}$ & This study \\
\hline $\mathrm{pfK} \Delta A s c \mathrm{I}$ & pfK with a deletion of 19.3-kbp AscI fragment; $\mathrm{Km}^{\mathrm{r}} \mathrm{Cm}^{\mathrm{r}}$ & This study \\
\hline pK18mobsacB & Mobilizable cloning vector; ColE1-oriV mob sacB $\left(\right.$ sucrose $\left.^{\mathrm{s}}\right) \mathrm{Km}^{\mathrm{r}}$ & Schäfer et al., 1994 \\
\hline $\mathrm{pK} 18 \mathrm{msr}$ & pK18mobsacB with repABC of pTi-SAKURA; $\mathrm{Km}^{\mathrm{r}}$ & This study \\
\hline pMGTrep 1 & pK18mobsacB with $\mathrm{Gm}^{\mathrm{r}}$ gene cassette and repABC of pTi-SAKURA; $\mathrm{Km}^{\mathrm{r}} \mathrm{Gm}^{\mathrm{r}}$ & Uraji et al., 2002 \\
\hline pK18mssr & pK18msr with $600-\mathrm{bp}$ NlaIII fragment (tiorf25) of pTi-SAKURA; $\mathrm{Km}^{\mathrm{r}}$ & This study \\
\hline pJP5603 & Mobilizable cloning vector; R6K-ori mob $\mathrm{Km}^{\mathrm{r}}$ & Penfold and Pemberton, 1992 \\
\hline pJP5603rep & pJP5603 with repABC of pTi-SAKURA; $\mathrm{Km}^{\mathrm{r}}$ & This study \\
\hline pJP5608 & Mobilizable cloning vector; R6K-ori mob $\mathrm{Tc}^{\mathrm{r}}$ & Penfold and Pemberton, 1992 \\
\hline pJP5608rep & pJP5608 with repABC of pTi-SAKURA; $\mathrm{Tc}^{\mathrm{r}}$ & This study \\
\hline pHRP311 & Broad host range cloning vector; oriT rep-incQ $\mathrm{Gm}^{\mathrm{r}} \mathrm{Sp}^{\mathrm{r}}$ & Parales and Harwood, 1993 \\
\hline pHRPN2 & pHRP311 with 2.6-kbp NheI fragment of pfK; $\mathrm{Gm}^{\mathrm{r}}$ & This study \\
\hline $\mathrm{pN} 2$ & pK18msr with 2.6-kbp NheI fragment of pfK; $\mathrm{Km}^{\mathrm{r}}$ & This study \\
\hline $\mathrm{pN} 5$ & pK18msr with 5.2-kbp NheI fragment of pfK; $\mathrm{Km}^{\mathrm{r}}$ & This study \\
\hline $\mathrm{pN} 7$ & pK18msr with 7.5-kbp NheI fragment of pfK; $\mathrm{Km}^{\mathrm{r}}$ & This study \\
\hline $\mathrm{pN} 12$ & pK18msr with 11.9-kbp NheI fragment of pfK; $\mathrm{Km}^{\mathrm{r}}$ & This study \\
\hline $\mathrm{pN} 2 \Delta N s p \mathrm{~V}$ & $\mathrm{pN} 2$ with deletion of 456 -bp $N s p \mathrm{~V}$ fragment; $\mathrm{Km}^{\mathrm{r}}$ & This study \\
\hline $\mathrm{pHP} 45 \Omega-\mathrm{Tc}$ & Potable $\mathrm{Tc}$ resistance gene $\left(\right.$ tet $C$ ) vector; $\mathrm{Ap}^{\mathrm{r}} \mathrm{Tc}^{\mathrm{r}}$ & Fellay et al., 1987 \\
\hline pBIN19 & Binary vector; rep-incP oriT $\mathrm{Km}^{\mathrm{r}}$ & Bevan, 1984 \\
\hline pBINN2 & pBIN19 with 2.6-kbp NheI fragment (tiorf24 and tiorf25) of pTi-SAKURA & This study \\
\hline pBINTc & pBIN19 with $\mathrm{Tc}^{\mathrm{r}}$ of $\mathrm{pHP} 45 \Omega-\mathrm{Tc} ; \mathrm{Tc}^{\mathrm{r}} \mathrm{Km}^{\mathrm{r}}$ & This study \\
\hline pN2T-r & $\begin{array}{l}\text { pK18mobsacB with 2.6-kbp NheI fragment of pTi-SAKURA and 1.7-kbp T-DNA fragment } \\
\text { of pTiC58; } \mathrm{Km}^{\mathrm{r}}\end{array}$ & This study \\
\hline pN2G-r & $\begin{array}{l}\mathrm{pK} 18 m o b s a c B \text { with } 4.7-\mathrm{kbp} \mathrm{XbaI} \text { fragment containing disrupted tiorf } 25 \text { by } \mathrm{Gm}^{\mathrm{r}} \text { insertion } \\
\text { mutagenesis; } \mathrm{Km}^{\mathrm{r}}\end{array}$ & This study \\
\hline pUC19Gm & pUC19 with 2.9-kbp PstI fragment containing $\mathrm{Gm}^{\mathrm{r}}$ gene cassette; $\mathrm{Gm}^{\mathrm{r}} \mathrm{Ap}^{\mathrm{r}}$ & Our collection \\
\hline
\end{tabular}

\footnotetext{
*) Nucleotide coordinate numbers indicate the position of the fragment in pTi-SAKURA.
} 
S17-1 $\lambda$ pir cells harboring a plasmid and recipient $E$. coli Sy327 cells were cultured in LB medium until the cell density reached an $\mathrm{OD}_{600}$ of 1 . Approximately $1.0 \times 10^{8}$ donor cells were washed with $0.9 \%(\mathrm{w} / \mathrm{v}) \mathrm{NaCl}$ and then mixed with the same number of recipient cells in $5 \mathrm{ml}$ of LB medium. After incubation at $37^{\circ} \mathrm{C}$ for 1 hour, $50-\mu \mathrm{l}$ aliquots were plated onto LB agar supplemented with rifampicin and other antibiotics that were selective for recipient cells that had acquired incoming plasmid.

Electroporation was performed as described by Wise et al. (2006) using a Cell-Porator (BRL, Gaithersburg U.S.A) with Bio-Rad Pulser cubettes ( $1 \mathrm{~mm}$ electrode gap ) under the following conditions: voltage, $300 \mathrm{~V}$; capacitance, $330 \mu \mathrm{F}$; impedance, low ohms; charge rate, fast; voltage boost resistance, $4 \mathrm{~K}$. After electroporation the cells were immediately re-suspended in $1 \mathrm{ml}$ of SOC medium, and incubated at $28^{\circ} \mathrm{C}$ with gentle shaking for 1 hour.

Ejection ratio in conjugation In order to determine the ejection ratio of the resident plasmid after introduction of another plasmid, 100 transconjugant colonies selected for incoming plasmid markers were streaked onto LB agar plates with antibiotics to which the resident and incoming plasmids conferred resistance. When the resident plasmid was a Ti plasmid, growth on $\mathrm{AB}$ minimal agar with nopaline $(2 \mathrm{mg} / \mathrm{ml})$ as the sole source of carbon was used instead of examination of antibiotic resistance, because pTi-SAKURA and pTiC58 code for nopaline utilization genes. After incubation at $28^{\circ} \mathrm{C}$ for 2 days, growth on the selective agar media was examined to distinguish transconjugants that still retained the resident plasmid from resident-plasmid-less transconjugants.

Loss ratio in successive cultivation Agrobacterium cells were cultured overnight in $\mathrm{LB}$ at $37^{\circ} \mathrm{C}$. Then, $1 \times$ $10^{8}$ cells were inoculated into fresh $\mathrm{LB}$ to repeat the overnight culture. The serial cultivation was repeated 5 times in total. The final culture was diluted and spread on LB agar to establish single colonies. The presence and absence of Ti plasmid in the colonies were checked by colony hybridization using virB gene fragment as a probe.

Homology and motif/domain search Searches for DNA and protein homologs in the DNA databases were carried out using the FASTA program (http://www.ddbj. nig.ac.jp/search/fasta-j.html). Motif/domain search was performed using the MOTIF program (http://motif.genome. jp/) and the Pfam program (http://www.sanger.ac.uk/ Software/Pfam/).

Extraction of RNA and RT-PCR Logarithmically growing cells were lysed by vortexing with glass beads in the presence of SDS, phenol and chloroform principally as described elsewhere (Suzuki et al., 1989). RNA was purified from the cell extract by treatment with phenol/ chloroform, then treatment with DNase and proteinase followed by ethanol precipitation. For cDNA synthesis, $10 \mu \mathrm{g}$ of the total RNA were used as a template. cDNA synthesis was carried out using reverse transcriptase ReverTra Ace (Toyobo, Osaka) in accordance with the manufacturer's instructions. An oligonucleotide primer (5'-tcgaagctcatcgtgccacatct-3') complementary to the 3' end region of the tiorf 25 open reading frame (ORF) was used as a primer for the reverse transcription (Fig. 3B). Subsequent PCR amplification was performed using KOD Dash DNA polymerase (Toyobo, Osaka) in accordance with the standard method. The gene-specific primer and a forward primer (5'-tatgcggaggcgcatccgaagg-3'), the corresponding sequence of which is located in the middle of tiorf24, were used for the PCR amplification (Fig. 3B).

\section{RESULTS}

Mapping of the locus that enhances incompatibility in pTi-SAKURA The large variable region (VAR) was thought to contain a region that makes pTi-SAKURA more resistant to interference by incoming incompatible repABC replicons than pTiC58. In order to localize the responsible region, we constructed five rep $A B C$ plasmids. As shown in Fig. 1, pfK and pfF contained a portion of the pTi-SAKURA VAR region and pfM harbored another portion of VAR, whereas pfI carried the vir region without

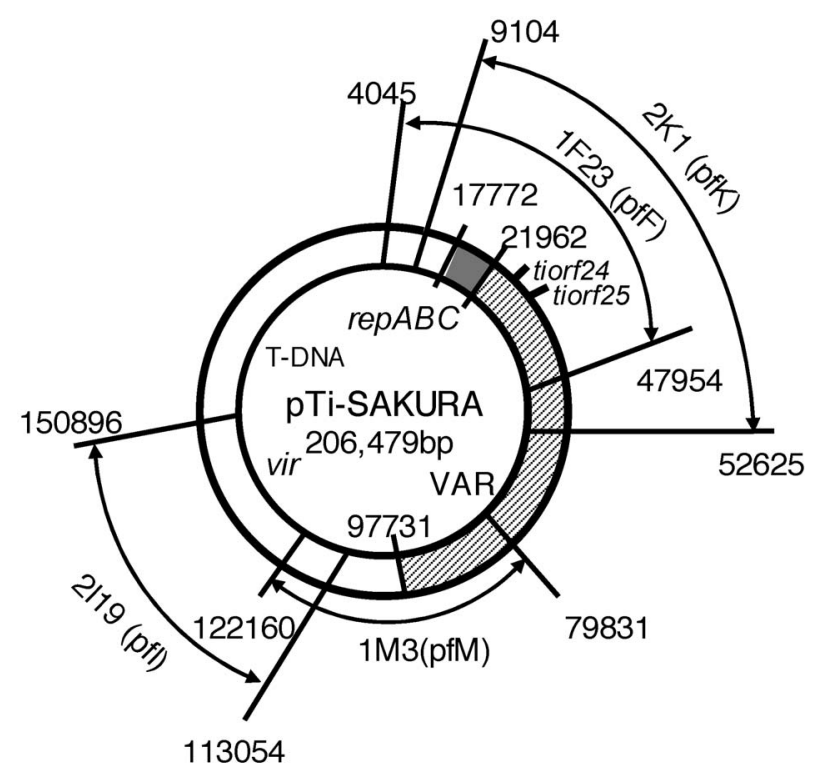

Fig. 1. Structure of pTi-SAKURA and the four derivative fosmid clones used in this study. The gray region indicates the repABC operon. The hatched region indicates the large variable region (VAR). Arches outside of the Ti plasmid circle indicate the regions that are contained in each fosmid clone. Shown in parentheses are the fosmids with oriT and $\mathrm{Km}^{\mathrm{r}}$ genes. 
VAR, and a small vector plasmid, pK18msr, possessed only repABC (negative control). We used pTi-SAKURA as a positive control in the next experiment.

The mini Ti plasmids and the vector were introduced into a Ti-less strain, MNS-1. Then, the incoming repABC plasmid, pJP5608rep, was introduced by conjugation, in order to evaluate the five plasmids. As shown in Fig. 2A, MNS-1 harboring pfK or pfF exhibited low transconjugant efficiency, like that harboring pTi-SAKURA. In contrast, strains possessing pfM or pfI exhibited high efficiency, which was as high as that of MNS-1 containing the vector plasmid. The difference in efficiency between the two plasmid groups was greater than about 20 -fold.

Using the cells with mini $\mathrm{Ti}$ as a recipient, all of the transconjugant colonies examined (100 colonies) were sensitive to kanamycin, suggesting that the resident mini Ti plasmid, which determines kanamycin resistance, was excluded in every transconjugant (data not shown).

pfK and pfF share a 39-kbp segment of pTi-SAKURA (Fig. 1). Thus, the common overlapping region shared by the two plasmids should contain the genes responsible for the effect described above. We localized the effective region to a 2.6-kbp NheI fragment using a series of deletion plasmids and subclone plasmids, as shown in Fig. 3A.

To discriminate whether the suppression takes place during the conjugational entry process or vegetative replication process after the conjugation, we introduced the incoming plasmid by electroporation in place of conjugation. As shown in Fig. 2B, the 2.6-kbp NheI fragment decreased the efficiency of transformation via electroporation 7.4-fold. This result indicates that the effect by the 2.6-kbp NheI fragment is not due to inefficient cellcell interaction during conjugation.

In order to know whether the 2.6-kbp NheI fragment affects conjugation efficiency when the fragment is present in the incoming plasmid in the conjugation assay, pN2 was introduced into the MAFF301001rif strain by conjugation. The transconjugant efficiency of $\mathrm{pN} 2$ was about ten times higher than that of vector plasmid (Fig. $2 \mathrm{C})$. Thus, the fragment is effective even when it is on the incoming plasmid.

On examination of the nucleotide sequence of pTiSAKURA (Hattori et al., 2000; Suzuki et al., 2000), the 2.6-kbp NheI fragment was found to cover nucleotide

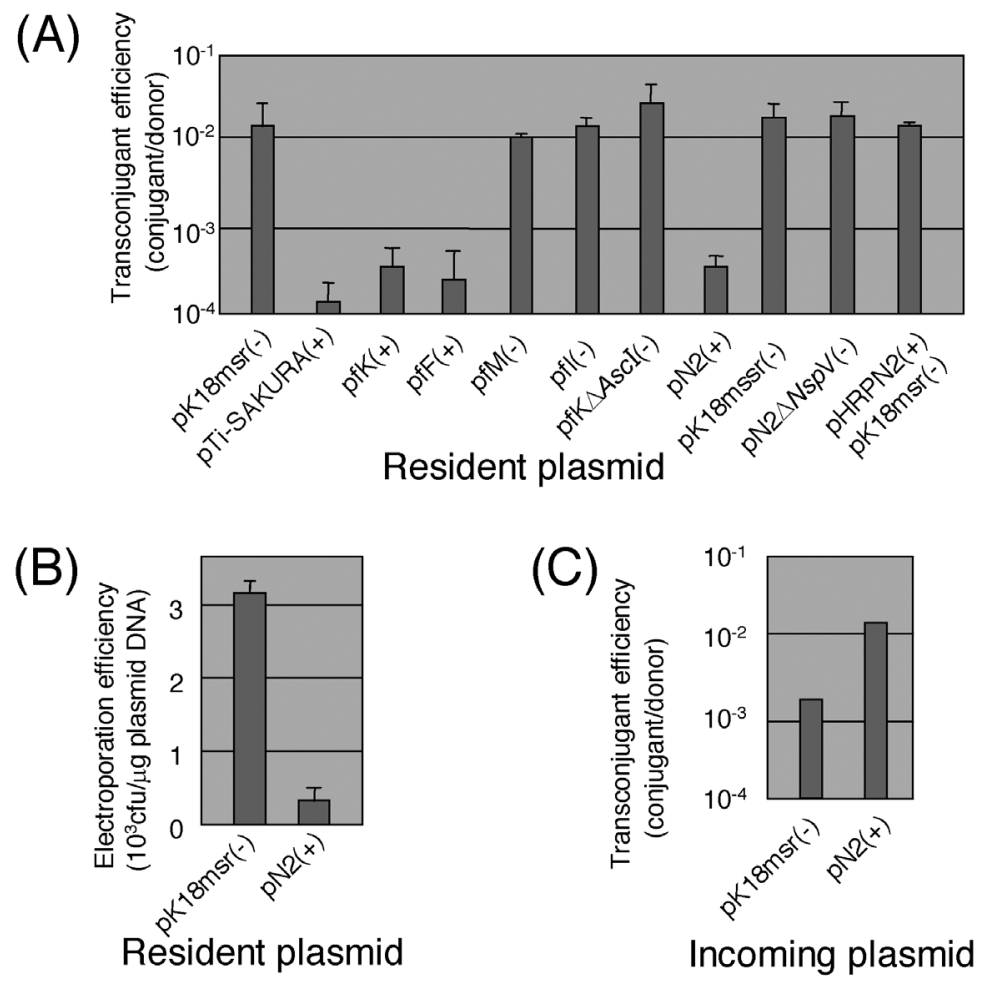

Fig. 2. Frequency of transconjugant formation induced by incompatible plasmids. (A) Agrobacterium tumefaciens MNS-1 harboring various resident plasmids was used as recipient for conjugation with donor E. coli S17-1 $\lambda$ pir (pJP5608rep). Each value is the average of at least three independent experiments. Thin vertical bars represent standard deviations. (B) Introduction of pMGTrep1 into the C58C1 harboring plasmid with or without the 2.6-kbp NheI fragment by electroporation. (C) Results of reciprocal experiments. A. tumefaciens MAFF301001rif strain was used as conjugal recipient, $E$. coli S17-1 $\lambda$ pir harboring plasmid with or without 2.6-kbp NheI fragment was used as conjugal donor. + and - in parenthesis indicate presence and absence of the 2.6-kbp NheI fragment, respectively. 
positions 23587 to 26207 in pTi-SAKURA. The fragment codes for two complete ORFs (tiorf24 and tiorf25) (Fig. $3 \mathrm{~B})$. In order to confirm that the two ORFs are responsible for suppressing repABC plasmid incursion, deletion mutants were constructed (Fig. 3B). Cells with a plasmid lacking either one of the two ORFs $(\mathrm{pN} 2 \Delta N s p \mathrm{~V}$, pK18mssr) allowed entry of the incoming plasmid with similar efficiency to that observed in cells with the vector plasmid (Fig. 2A and Fig. 3B).

Effect of the 2.6-kbp NheI region on intact Ti plasmids The 2.6-kbp NheI fragment affected whole Ti plasmids in a manner different from the effect on the small plasmids. C58rif, which harbors pTiC58, allowed introduction of a repABC plasmid as efficiently as MAFF301001rif, which harbors pTi-SAKURA (Table 2). However, the ejection ratio of pTiC58 in transconjugants $(47 \%)$ was higher than that of pTi-SAKURA in transconjugants $(6 \%)$ (Table 2 ). Here the ejection ratio was defined as the percentage of transconjugant cells which lost the resident plasmid. Addition of the 2.6-kbp NheI fragment to pTiC58 (see pTiC58px in Table 2) decreased the ejection ratio of pTiC58 in transconjugants down to $1 \%$, although the addition had only a negligible effect on the transconjugant efficiency. Furthermore, a similar phenomenon was also observed in MAFF301001rif. A tiorf25 mutant, pTi-SAKURAmx, was ejected more frequently (53\%) than wild-type pTi-

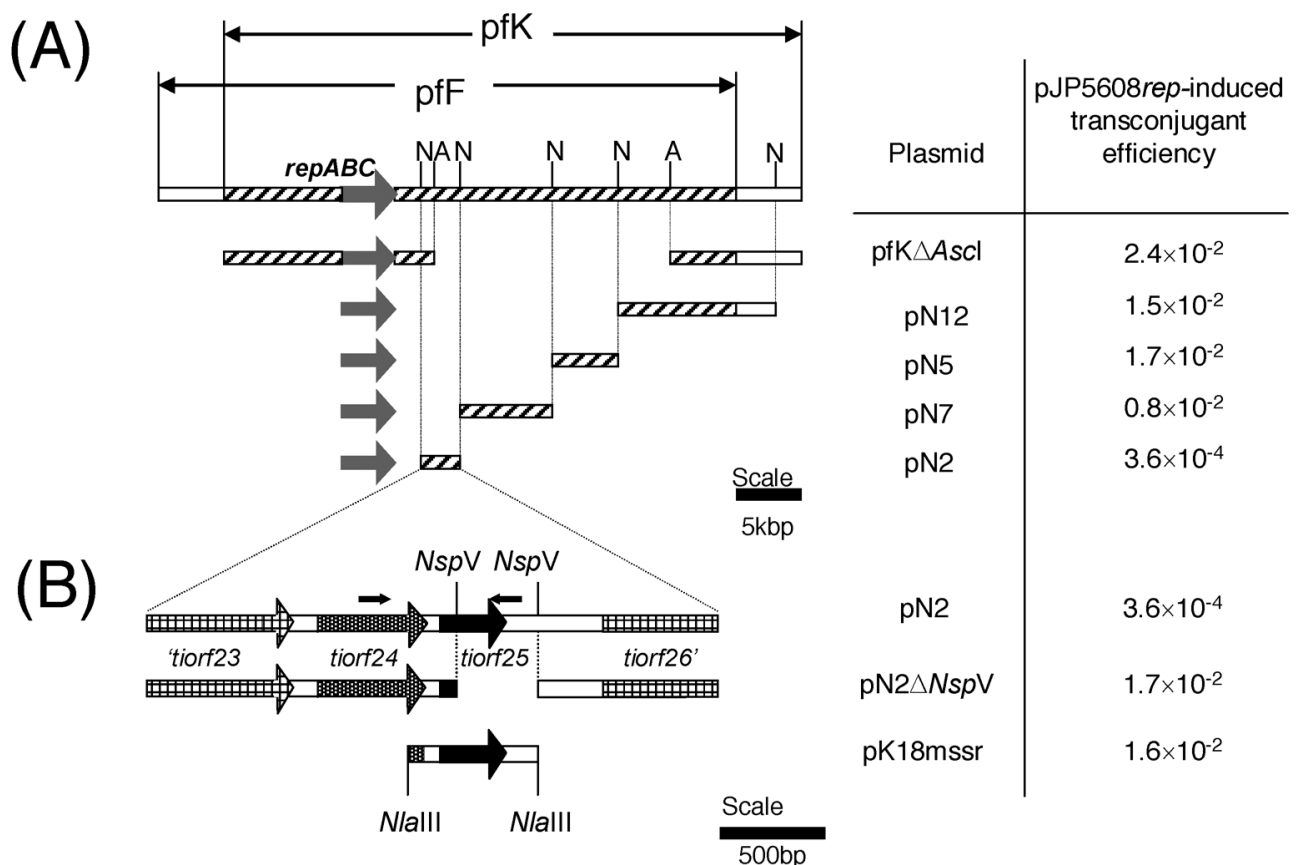

Fig. 3. Transconjugant efficiency of cells harboring a VAR portion of pTi-SAKURA. Left panel, physical map; right panel, efficiency of transconjugant colony formation. (A) Recombinant fosmid clones and subclone plasmids. Gray arrows indicate the repABC operon. Hatched boxes indicate the region shared by pfF and pfK. Restriction site: $\mathrm{N}$, NheI; A, AscI. (B) Enlarged physical map of the 2.6-kbp NheI fragment. Two small arrows indicate the locations and directions of the two oligonucleotide primers used for RT-PCR (Fig. 4).

Table 2. Influence of addition and deletion of the 2.6-kbp NheI fragment to Ti plasmids

\begin{tabular}{ccccc}
\hline \hline Resident plasmid & $\begin{array}{c}\text { Transconjugant efficiency } \\
\text { (conjugant/donor) }\end{array}$ & $\begin{array}{c}\text { Ejection ratio (\%) of } \\
\text { resident plasmid }\end{array}$ & $\begin{array}{c}\text { Loss ratio (\%) } \\
\text { of resident plasmid }\end{array}$ \\
\hline pTi-SAKURA & $(+)^{*}$ & $1.4 \times 10^{-4}$ & 6 & NT \\
pTi-SAKURAmx & $(-)$ & $1.2 \times 10^{-4}$ & 53 & NT \\
\hline pTiC58 & $(-)$ & $2.7 \times 10^{-4}$ & 47 & 90 \\
pTiC58px & $(+)$ & $2.1 \times 10^{-4}$ & 1 & 0 \\
\hline
\end{tabular}

The ejection ratio is the percentage of colonies which lost the resident plasmid after conjugation. The loss ratio is the percentage of colonies that lost the resident plasmid after successive cultivation (see MATERIALS AND METHODS section).

* presence (+) and absence (-) of the $2.6-\mathrm{kbp}$ NheI region.

NT means Not Tested. 
SAKURA (6\%). As shown in Table 2, the ejection ratio of the tiorf $25:: \mathrm{Gm}^{\mathrm{r}}$ mutant (pTi-SAKURAmx) of pTiSAKURA was as high as that of pTiC58. The mutation had only a negligible effect on suppression of the entry of rep $A B C$ plasmids. These results indicate that the 2.6kbp NheI fragment is responsible for the lower ejection ratio of pTi-SAKURA than of pTiC58. In contrast to the intact Ti plasmids, $\mathrm{pN} 2$, the small plasmid harboring the 2.6-kbp NheI fragment showed a significantly higher ejection ratio (4\%) than pTi-SAKURA (data not shown).

In order to examine whether the addition of the $2.6-\mathrm{kbp}$ NheI fragment affects the segregational stability of pTiC58, we measured the loss ratio of pTiC58 with or without the fragment after serial cultivation. After 5 repetitions of culturing at $37^{\circ} \mathrm{C}, 90 \%$ of the colonies lost pTiC58. In contrast, no colony lost pTiC58px under the same experimental conditions (Table 2). This result shows that the 2.6-kbp NheI fragment increased the segregational stability.

Gene expression and mode of action of tiorf 24 and tiorf25 Transcription of tiorf24 and tiorf25 in vivo was investigated by RT-PCR experiments. RNA isolated from cells harboring various plasmids was subjected to reverse transcription as described in MATERIALS AND METHODS. The oligonucleotide primers used for PCR were located at the 3'-end of tiorf 25 and in the middle of tiorf24, respectively (Fig. 3B). As shown in Fig. 4, a PCR product of about 550-bp in size was observed when total

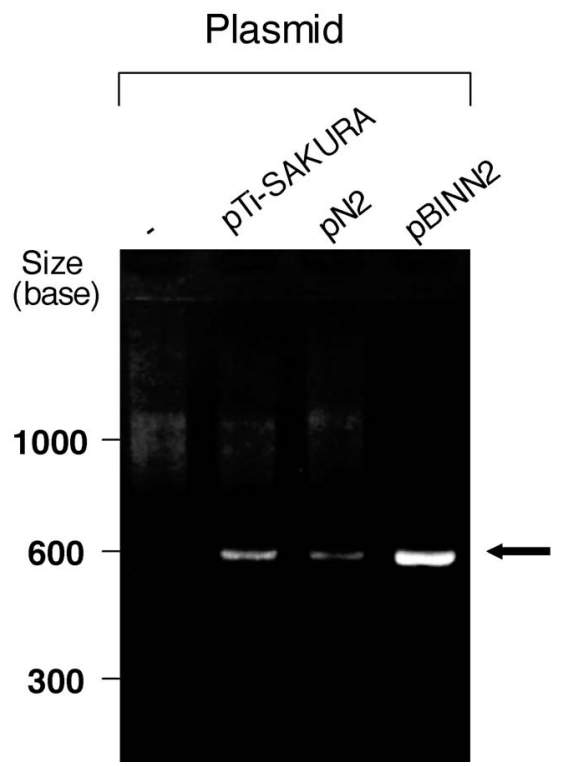

Fig. 4. RT-PCR analysis of transcription from tiorf24 and tiorf25 genes. RNAs extracted from A. tumefaciens MNS-1 harboring a plasmid were used as templates for the reverse transcriptase reaction. PCR amplification was carried out using the oligonucleotide primers shown in Fig. 3B and MATERIALS AND METHODS.
RNA extracted from MAFF301001rif and MNS-1 harboring $\mathrm{pN} 2$ or pBINN2 was used, whereas no such fragment was produced using total RNA from MNS-1 without the plasmids. Increased expression was observed in cells harboring pBINN2, which contained the 2.6-kbp NheI fragment on a multicopy-type vector. These data indicate that tiorf 24 and tiorf 25 are transcribed as a single mRNA.

In order to determine whether the tiorf 24 and tiorf 25 genes can act on plasmids not only in a cis but also in a trans manner, an incQ-type replicon, pHRPN2, which has the 2.6-kbp NheI fragment, was introduced into MNS-1 harboring a repABC vector plasmid, pK18msr. MNS-1 harboring pHRPN2 and pK18msr allowed entry of incoming repABC plasmid at the same level as cells with pK18msr only (Fig. 2A). These results show that tiorf24 and tiorf 25 are able to act effectively only in a cis manner. In addition, we investigated whether the 2.6kbp segment of pTi-SAKURA was effective even if the incoming and resident plasmids were of different replication types. MNS-1 harboring pN2 allowed entry of an incQ-type replicon, pHRP311, and an incP-type replicon, pBINTc, with the same efficiency as MNS-1 and MAFF301001rif (Fig. 5A and B). This observation indicates that the resident and incoming plasmids must have the same type of replicon for the two ORFs to exert their effect. This confirmed that the effect of the 2.6-kbp segment was caused by incompatibility enhancement.

We next examined whether the incompatibility-enhancing effect of tiorf 24 and tiorf25 takes place even when the two genes are located on replicons other than the repABC type or even when the two genes are contained in $E$.
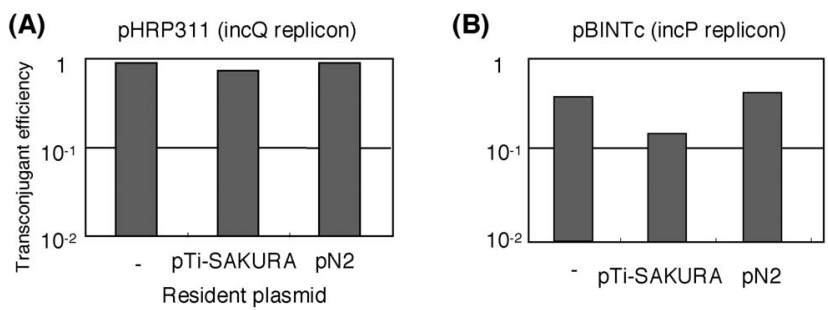

(C)
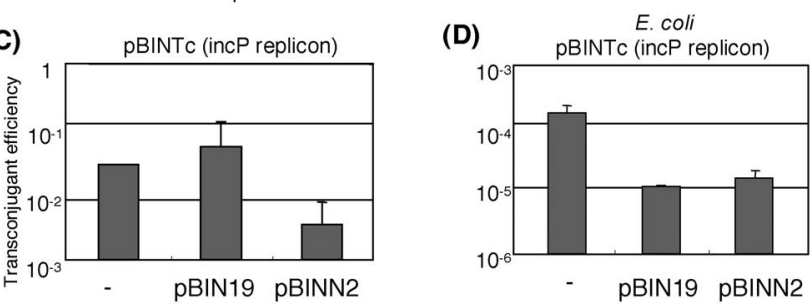

Fig. 5. Efficiency of introduction of incQ and incP replicons into $A$. tumefaciens and $E$. coli. Cells harboring a resident plasmid were subjected to conjugation with donor $E$. coli S17-1 $\lambda$ pir harboring an incoming plasmid shown in the upper part of each panel. A. tumefaciens MNS-1 (panels A, B and C) and E. coli Sy327 $\lambda$ pir (panel D) harboring a resident plasmid as shown underneath each bar were used as recipient. 
Table 3. Homologues of the Tiorf25 protein

\begin{tabular}{|c|c|c|c|c|c|}
\hline Accession No. & Gene or ORF & Organism & $\begin{array}{l}\text { Amino acid } \\
\text { Identity }(\%)\end{array}$ & E value & Feature \\
\hline CAD84464 & NE0553 & Nitrosomonas europaea ATCC 19718 & 50 & $5 \mathrm{e}^{-12}$ & PIN domain \\
\hline EAQ19904 & PnapDRAFT_1562 & Polaromonas naphthalenivorans CJ2 & 37 & $1 \mathrm{e}^{-9}$ & $\begin{array}{l}\text { Similar to Agrobacterium } \\
\text { tumefaciens Yle }\end{array}$ \\
\hline ABC93127 & $R H E \_P B 00085$ & Rhizobium etli CFN 42 & 44 & $7 \mathrm{e}^{-8}$ & $\begin{array}{l}\text { Putative plasmid stabilization } \\
\text { Protein }\end{array}$ \\
\hline AAK64896 & Sma045 & Sinorhizobium meliloti 1021 & 33 & $1 \mathrm{e}^{-7}$ & $\begin{array}{l}\text { Homologous to possible plasmid } \\
\text { stability locus Yle from } \\
\text { A. tumefaciens octopine-type } \\
\text { Ti plasmid }\end{array}$ \\
\hline BAC47699 & Bll2434 & Bradyrhizobium japonicum USDA 110 & 41 & $2 \mathrm{e}^{-7}$ & Plasmid stability protein \\
\hline CAJ30068 & $\operatorname{MgI417}$ & Magnetospirillum gryphiswaldense & 43 & $3 \mathrm{e}^{-7}$ & $\begin{array}{l}\text { Putative plasmid stability-like } \\
\text { protein }\end{array}$ \\
\hline AAL03856 & $R C 1318$ & Rickettsia conorii Malish 7 & 31 & $4 \mathrm{e}^{-7}$ & $\begin{array}{l}\text { Similarity to plasmid stability } \\
\text { protein }\end{array}$ \\
\hline
\end{tabular}

coli. The 2.6-kbp NheI fragment on the incP vector pBIN19 (see pBINN2) suppressed the entry of another incP-type replicon pBINTc into MNS-1 16-fold. However, such suppression was not detected in $E$. coli (Fig. 5C and D). These results show that the $2.6-\mathrm{kbp}$ NheI fragment confers incompatibility-enhancing effect to the resident plasmid when the same type replicon is introduced in Agrobacterium cells, but that the fragment does not contain an incompatibility-determining region itself.

Homology analysis using the FASTA program indicated that tiorf24 is an orphan $\mathrm{ORF}$, having no homologous $\mathrm{ORF}$ in the databases searched, and that tiorf25 is a homolog of $s t b B$, which is a part of the $s t b A B C D$ gene cluster. $s t b A B C D$ is a plasmid stability locus in Pseudomonas syringae pv. tomato (Hanekamp et al., 1997). Neither Pseudomonas stbB nor any stbB homologues (Table 3) have been characterized functionally yet. No matching motif was detected by MOTIF analysis. However, domain searching using the Pfam program detected the PIN (twitching motility protein PilT $\mathrm{N}$-terminus) domain in the Tiorf25 protein ( score $=23.0$ bits, $\mathrm{E}$ value $=8 \mathrm{e}^{-07}$ ).

\section{DISCUSSION}

This study showed that the region which is responsible for plasmid stability as well as incompatibility-enhancement in pTi-SAKURA is located on a $2.6-\mathrm{kbp}$ NheI fragment, which contains tiorf24 and tiorf25. The $2.6-\mathrm{kbp}$ NheI fragment has the ability to inhibit transformation by an incoming plasmid only when the resident and incoming plasmids belong to the same incompatibility group. This inhibition occurred regardless of the plasmid introduction procedure (conjugation or electroporation). Thus, inhibition should occur by a mechanism that operates after cell-cell contact. Because the 2.6-kbp NheI fragment was effective on repABC replicons and an
incP replicon (Fig. 2A and Fig. 5C), its effect is not directly involved in replicon-specific replication, stabilization, or incompatibility mechanisms. Since two different replication type plasmids containing the 2.6 -kbp NheI fragment ( $\mathrm{pN} 2$ and $\mathrm{pHRPN2}$ ) can replicate independently in the same Agrobacterium cell (data not shown), it is unlikely that this region is an incompatibility-determining site, for example one that interacts directly with cellular centromere-like components. Addition of the 2.6$\mathrm{kbp}$ NheI fragment to pTiC58 also decreased the loss ratio during growth at $37^{\circ} \mathrm{C}$. The $2.6-\mathrm{kbp}$ NheI fragment determines higher plasmid stability, and plasmid incompatibility enhancement may be reflected by increasing segregational stability.

The 2.6-kbp NheI fragment contains two complete ORFs (tiorf24 and tiorf25). Our RT-PCR experiment showed that the two ORFs are transcribed as a single mRNA. tiorf24 is an orphan gene, whereas tiorf 25 is a homologue of a plasmid stabilization protein (Table 3). The putative plasmid stabilizing genes listed in Table 3 are homologues of $s t b B$ on the B-plasmid of Pseudomonas syringae pv. tomato (Hanekamp et al., 1997). It has been reported that the $s t b B$ gene is encoded in the plasmid stabilization cluster (stbABCD), but its function is still unknown. These data also suggest that the incompatibility-enhancing effect of tiorf24 and tiorf25 is caused by a plasmid stabilization mechanism. Our domain search using the Pfam program detected the PIN (twitching motility protein PilT N-terminus) domain in Tiorf25. PIN is a compact domain of about 100 amino acid residues, with two conserved aspartate residues. We also detected the PIN domain in all proteins listed in Table 3. Leptospira interrogans gene vapC has a PIN domain and is homologous to the putative stabilizer genes listed in Table 3 . The vapC gene encodes a toxic protein of the toxin-antitoxin system (TA system), which also involves the antitoxin gene vapB 
(Zhang et al., 2004). These genes are closely located, suggesting an operonic structure, as generally found in TA systems. Although the Leptospira TA system is located in the chromosome, the region has the ability to stabilize an unstable plasmid when added to the plasmid. Because tiorf25 also contains a PIN domain and together with adjacent tiorf24 comprises an operon, the Ti plasmid stabilizing effect of two ORFs might be caused by a TA mechanism.

The difference in the plasmid ejection ratio in cells containing pTi-SAKURA and pTiC58 in response to introduction of incompatible repABC replicons is contingent on tiorf 24 and tiorf25. Furthermore, differences in exclusion and permissiveness for rep $A B C$ plasmid incursion were significant between intact Ti plasmids and smaller plasmids such as pN2 (data not shown). It is likely that an additional stabilization factor causes the difference in permissiveness between intact $\mathrm{Ti}$ and small $\operatorname{rep} A B C$ plasmids. An alternative explanation is the contribution of plasmid size differences, since the stability of yeast artificial chromosomes depends on their size (Zakian et al., 1986), and repABC replicons are generally huge plasmids or chromosomes, such as the linear chromosome of A. tumefaciens C58 (about 2,000 kbp), pSymb of Sinorhizobium meliloti (about 1,700 kbp) and $\mathrm{Ti}$ and $\mathrm{Ri}$ plasmids (about $200 \mathrm{kbp}$ ) (Galibert et al., 2001; Goodner et al., 2001; Moriguchi et al., 2001).

The authors are grateful to Mrs. J. Bautista-Zapanta for her helpful comments.

\section{REFERENCES}

Austin, S. J., and Nordström, K. (1990) Partition-mediated incompatibility of bacterial plasmids. Cell 60, 351-354.

Bevan, M. (1984) Binary Agrobacterium vectors for plant transformation. Nucleic Acids Res. 12, 8711-8721.

Chilton, M. D., Currier, T. C., Farrand, S. K., Bendich, A. J., Gordon, M. P., and Nester, E. W. (1974) Agrobacterium tumefaciens DNA and PS8 bacteriophage DNA not detected in crown gall tumors. Proc. Natl. Acad. Sci. USA 71, 36723676.

De Costa, D. M., Suzuki, K., Sato, M., and Yoshida, K. (2001) Genome analysis of Agrobacterium tumefaciens: linkage map and genetic features of the left region of the linear chromosome. Genes Genet. Syst. 76, 363-371.

Fellay, R., Frey, J., and Krisch, H. (1987) Interposon mutagenesis of soil and water bacteria: a family of DNA fragments designed for in vitro insertional mutagenesis of gram-negative bacteria. Gene 52, 147-154.

Galibert, F., Finan, T. M., Long, S. R., Pühler, A., Abola, P., Ampe, F., Barloy-Hubler, F., Barnett, M. J., Becker, A., Boistard, P., Bothe, G., Boutry, M., Bowser, L., Buhrmester, J., Cadieu, E., Capela, D., Chain, P., Cowie, A., Davis, R. W., Dréano, S., Federspiel, N. A., Fisher, R. F., Gloux, S., Godrie, T., Goffeau, A., Golding, B., Gouzy, J., Gurjal, M., Hernandez-Lucas, I., Hong, A., Huizar, L., Hyman, R. W., Jones, T., Kahn, D., Kahn, M. L., Kalman, S., Keating, D. H., Kiss, E., Komp, C., Lelaure, V., Masuy, D., Palm, C.,
Peck, M. C., Pohl, T. M., Portetelle, D., Purnelle, B., Ramsperger, U., Surzycki, R., Thebault, P., Vandenbol, M., Vorhölter, F. J., Weidner, S., Wells, D. H., Wong, K., Yeh, K. C., and Batut, J. (2001) The composite genome of the legume symbiont Sinorhizobium melilot. Science 293, 668672.

Goodner, B., Hinkle, G., Gattung, S., Miller, N., Blanchard, M., Qurollo, B., Goldman, B. S., Cao, Y., Askenazi, M., Halling, C., Mullin, L., Houmiel, K., Gordon, J., Vaudin, M., Iartchouk, O., Epp, A., Liu, F., Wollam, C., Allinger, M., Doughty, D., Scott, C., Lappas, C., Markelz, B., Flanagan, C., Crowell, C., Gurson, J., Lomo, C., Sear, C., Strub, G., Cielo, C., and Slater, S. (2001) Genome sequence of the plant pathogen and biotechnology agent Agrobacterium tumefaciens C58. Science 294, 2323-2328.

Hanekamp, T., Kobayashi, D., Hayes, S., and Stayton, M. M. (1997) Avirulence gene D of Pseudomonas syringae pv. tomato may have undergone horizontal gene transfer. FEBS Lett. 415, 40-44.

Hattori, Y., Uraji, M., Suzuki, K., Ohta, N., Iwata, K., Kato, A., and Yoshida, K. (2000) Gene list on a plant tumor-inducing plasmid, pTi-SAKURA in Agrobacterium tumefaciens MAFF301001. DNA Res. 7, 371-380.

Holsters, M., Hernalsteens, J. P., Van Montagu, M., and Schell, J. (1982) Ti plasmids of Agrobacterium tumefaciens: The nature of the TIP. In: Molecular Biology of Plant tumors (eds.: G. kahl, and J. S. Schell), pp. 269-298. Academic Press, New York.

Li, P., and Farrand, S. K. (2000) The replicator of the nopalinetype Ti plasmid pTiC58 is a member of repABC family and is influenced by the TraR-dependent quorum-sensing regulatory system. J. Bacteriol. 182, 179-188.

Miller, V. L., and Mekalanos, J. J. (1988) A novel suicide vector and its use in construction of insertion mutations: osmoregulation of outer membrane proteins and virulence determinants in Vibrio cholerae requires toxR. J. Bacteriol. 170, 2575-2583.

Moriguchi, K., Maeda, Y., Satou, M., Hardayani, N. S., Kataoka, M., Tanaka, N., and Yoshida, K. (2001) The complete nucleotide sequence of a plant root-inducing (Ri) plasmid indicates its chimeric structure and evolutionary relationship between tumor-inducing ( $\mathrm{Ti}$ ) and symbiotic (Sym) plasmids in Rhizobiaceae. J. Mol. Biol. 307, 771-784.

Nishiguchi, R., Takanami, M., and Oka, A. (1987) Characterization and sequence determination of the replicator region in the hairy-root-inducing plasmid pRiA4b. Mol. Gen. Genet. 206, 1-8.

Novick, R. P. (1987) Plasmid incompatibility. Microbiol. Rev. 51, 381-395.

Parales, R. E., and Harwood, C. S. (1993) Construction and use of a new broad-host-range $l a c Z$ transcriptional fusion vector, pHRP309, for gram ${ }^{-}$bacteria. Gene 133, 23-30.

Penfold, R. J., and Pemberton, J. M. (1992) An improved suicide vector for construction of chromosomal insertion mutations in bacteria. Gene 118, 145-146.

Ramírez-Romero, M. A., Soberón, N., Pérez-Oseguera, A., TéllezSosa, J., and Cevallos, M.A. (2000) Structural elements required for replication and incompatibility of the Rhizobium etli symbiotic plasmid. J. Bacteriol. 182, 3117-3124.

Rigottier-Gois, L., Tumer, S. L., Young, J. P. W., and Amarger, N. (1998) Distribution of repC plasmid-replication sequences among plasmids and isolates of Rhizobium leguminosarum bv. viciae from field populations. Microbiology 144, 771780 .

Sambrook, J., Fritsch, E. F., and Maniatis, T. (1989) Molecular 
cloning: A Laboratory Manual, 2nd Edition. Cold Spring Harbor Laboratory, Cold Spring Harbor, New York.

Schäfer, A., Tauch, A., Jäger, W., Kalinowski, J., Thierbach, G., and Pühler, A. (1994) Small mobilizable multi-purpose cloning vectors derived from the Escherichia coli plasmids pK18 and pK19: selection of defined deletions in the chromosome of Corynebacterium glutamicum. Gene 145, 69-73.

Simon, R., Priefer, U., and Pühler, A. (1983) A broad host range mobilization system for in vivo genetic engineering: transposon mutagenesis in Gram-negative bacteria. Bio/Technology 1, 784-794.

Suzuki, K., Hattori, Y., Uraji, M., Ohta, N., Iwata, K., Murata, K., Kato, A., and Yoshida, K. (2000) Complete nucleotide sequence of a plant tumor-inducing Ti plasmid. Gene 242, 331-336.

Suzuki, K., Ichikawa, K., and Jigami, Y. (1989) Yeast mutants with enhanced ability to secrete human lysozyme: isolation and identification of a protease-deficient mutant. Mol. Gen. Genet. 219, 58-64.

Suzuki, K., Iwata, K., and Yoshida, K. (2001) Genome analysis of Agrobacterium tumefaciens: construction of physical maps for linear and circular chromosomal DNAs, determination of copy number ratio and mapping of chromosomal virulence genes. DNA Res. 8, 141-152.

Suzuki, K., Ohta, N., Hattori, Y., Uraji, M., Kato, A., and Yoshida, K. (1998) Novel structural difference between nopaline- and octopine-type trbJ genes: construction of genetic and physical map and sequencing of trb/traI and rep gene clusters of a new Ti plasmid pTi-SAKURA. Biochim. Biophys. Acta 1396, 1-7.

Tabata, S., Hooykaas, P. J. J., and Oka, A. (1989) Sequence determination and characterization of the replicator region in the tumor-inducing plasmid pTiB6S3. J. Bacteriol. 171, $1665-1672$.

Uraji, M., Suzuki, K., and Yoshida, K. (2002) A novel plasmid curing method using incompatibility of plant pathogenic $\mathrm{Ti}$ plasmids in Agrobacterium tumefaciens. Genes Genet. Syst. 77, 1-9.

White, F. F., and Nester, E. W. (1980) Relationship of plasmids responsible for hairy root and crown gall tumorigenicity. J. Bacteriol. 144, 710-720.

Wise, A. A., Liu, Z., and Binns, A. N. (2006) Three methods for the introduction of foreign DNA into Agrobacterium. In: Agrobacterium Protocols second edition (eds.: Wang. K), pp. 43-53. Humana Press, New Jersey, USA.

Zakian, V. A., Blanton, H. M., Wetzel, L., and Dani, G. M. (1986) Size threshold for Saccharomyces cerevisiae chromosomes: generation of telocentric chromosomes form an unstable minichromosome. Mol. Cell. Biol. 6, 925-932.

Zhang, Y. X., Li, J., Guo, X. K., Wu, C., Bi, B., Ren, S. X., Wu, C. F., and Zhao, G. P. (2004) Characterization of a novel toxin-antitoxin module, VapBC, encoded by Leptospira interrogans chromosome. Cell Res. 14, 208-216. 